\title{
7-Eklerin semantik fonksiyonu üzerine: +lIk etmek / +lIk yapmak örneği
}

\section{Yusuf GÖKKAPLAN 1}

\begin{abstract}
APA: Gökkaplan, Y. (2020). Eklerin semantik fonksiyonu üzerine: +llk etmek / +lIk yapmak örneği. RumeliDE Dil ve Edebiyat Araştırmaları Dergisi, (21), 126-136. DOI: 10.29000/rumelide.835779.
\end{abstract}

\section{Öz}

Türkçe, bir sözcüğün yoğun anlam yükü ile kullanıldığı bir dildir. Türkçe bir sözcük cümle içerisindeki durum ve konumuna göre, bağlam içerisindeki anlam ilgilerine göre, ifade edildiği durum ve atmosfere göre farklı anlam içerik ve ilgisi ile kullanılabilmektedir. Bu durumlara sözcükleri ifade eden kişilerin kendi düşünce ve fikirleri de eklenince beklediğimizden daha yoğun bir anlam yükü ortaya çıkmaktadır. Sözcüklere yüklenen yoğun anlam çeşitliliği, ifade ettiğimiz bu durumların dışında ekler aracılığı ile de yapılabilmektedir. Sondan eklemeli bir dil olan Türkçede eklerin bir sözcüğe kattığı anlamsal farklılıklar oldukça fazladır. Bu yüzden Türkçede ekler sözcüklerin köklerinde anlamsal ve yapısal bir değişiklik yapıp yapmadıklarına göre sinıflandırılırlar. Bu noktadan hareketle Türkçede bir ekin sözcüğe yeni anlamlar yüklemek, sözcüğün türünde ve görevinde değişiklikler yapmak gibi önemli bir göreve sahip olduğunu söyleyebiliriz. Bu çalışmada, bir sözcüğe ulandığında ona farklı bir anlam ilgisi katan ve tek bir ek olarak değil de etmek ya da yapmak yardımcı fiilleri ile birlikte kullanılan +lIk yapmak, +lIk etmek kalıbının ulandığı sözcüklere yüklediği anlam ilgisi ele alınacaktır. Bu yolla yapılan sözcüklerin, günlük konuşma dilinde kazandığı yeni anlamının ve eğer sözlüklerde var ise burada verilen anlamlarının semantik çerçevede değerlendirilmesi yapılacaktır. Ĕ̆er her iki bağlamda da farklı anlam ilgisi var ise burada günlük konuşma dilinde kazandığı anlamı esas alarak yeniden değerlendirme yapılacaktır. Elde ettiğimiz bu anlamsal çerçeveyi, toplumsal tabaka farklılığından kaynaklanan dil kullanımını esas alarak burada ortaya çıkan farklı kullanımları W. Labov'un ayrılık kuramı çerçevesinde değerlendireceğiz.

Anahtar kelimeler: Anlambilim, toplumdilbilim, yapım eki, Türk dili

\section{The semantic function of suffixes: The example of +lIk etmek / +lIk yapmak}

\begin{abstract}
Turkish is a language in which a word may have multiple meanings. The meaning of a word in Turkish may be subject to change depending on its position in a sentence; the context; and the atmosphere in which it is articulated. The meaning may gain many more multiple dimensions than expected when the individual thoughts and opinions of the speaker are considered. Furthermore, the meaning may also change because of the suffixes. The semantic differences in Turkish, an agglutinative language, resulting from suffixes are numerous. Therefore, the suffixes in Turkish are classified according to whether or not they cause a semantic or structural difference. It is due to this reason that a suffix has such a significant role in a way it can change the meaning of a word, its type, and function. In this respect, this study will discuss the new semantic layer of a word through the addition of the suffix, +lIk etmek, which gives a word new meaning when added and which is used
\end{abstract}

Dr. Öğr. Üyesi, Kapadokya Üniversitesi, Beşeri Bilimler Fakültesi, Türk Dili ve Edebiyatı Bölümü (Nevşehir, Türkiye) yusuf.gokkaplan@kapadokya.edu.tr, ORCID ID: 0000 o001 65154762 [Araştırma makalesi, Makale kayıt tarihi: 28.10.2020-kabul tarihi: 20.12.2020; DOI: 10.29000/rumelide.835779]

Adres
Address

Istanbul Medeniyet University, Faculty of Education Sciences,

Turkish and Social Scinces Education, Turkish Language Teaching

Education, Cevizli Campus, Kartal-İstanbul /TURKEY

e-mail: editor@rumelide.com 


\begin{abstract}
together with etmek or yapmak rather than on its own. The semantic evaluations of the new meanings, gained in colloquial language, of the words neoterised in this way and their lexical meanings, if there is any, will be made. If the meaning changes depending on the context, a new evaluation will be made based on the meaning gained in colloquial language. The new semantic framework and new usages of words based on the different use of language resulting from difference in social background will be analyzed in the light of W. Labov's difference theory.
\end{abstract}

Keywords: Semantics, socio-linguistics, derivational affix, Turkish language

\title{
1. Giriş
}

Yapım ekleri Türkçede sözcüklerin hem anlamını hem de türünü değiştirerek yeni sözcüklerin türetilmesinde sıkça kullanılan eklerdir. Hem yazı hem de konuşma dilinde sıkça kullandığımız yapım eklerinin soyut ve somut kavramların ifadesinde ve bu kavramlardan yeni sözcüklerin türetilmesinde önemli rol oynadığını söyleyebiliriz. Bahsettiğimiz bu eklerden bir tanesi de +lIk yapım ekidir. Bu ek, yapım ekleri içinde sıkça kullanılmaktadır ve çeşitli adların türetilmesinde görev yapmaktadır. Dilimizde etkin bir sözcük türetme metodu olarak ele alabileceğimiz yapım ekleri üzerine yapılan çalışmalarda +lIk ekinin ses ve şekil özelliklerinden hareketle eklendikleri sözcüklerde gerçekleştirdiği tür ve anlam değişikliği esas alınmıştır. +lIk eki eklendiği sözcüklere yer adı, sıfat, alet adı, araç-gereç adı, meslek adı, rütbe adı, makam adı, soyut adlar, sayı adları, renk adları, bağlılık adı, özellik ve topluluk adı anlamları katarak yeni isimler yapan ve işlek olarak kullanılan bir ektir.

+lIk yapım ekinin yazı ve konuşma dilindeki kullanımlarına baktığımızda anlam yoğunluğunun düşündüğümüzden daha zengin olduğunu söyleyebiliriz. Hem yazı hem de konuşma dilinde sıkça kullandığımız yapım eklerinin soyut ve somut kavramların ifadesinde ve bu kavramlardan yeni sözcüklerin türetilmesinde de farklı görevlerle kullanıldığı görülmektedir. Özellikle yazı dilimize farklı bir pencere açan sosyal ortam yazışmaları da başta olmak üzere söz konusu eklerin çeşitli bağlamlarda, farklı anlam ifadesiyle kullanıldı̆̆ı dikkat çekmektedir. Bu çalışmada da, söz konusu edilen bağlamlarda, yazı ve konuşma dilimizde sıkça kullanılan +lIk yapım eki ve bu ekle bazı çekim eklerinin, yardımcı fiillerin birleşmesi ile ortaya çıan yeni yapının semantik yönü ele alınacaktır. Bu ek ile türetilmiş sözcüklerin ihtiva ettiği anlamlardan hareketle bu yapım eklerinin bir sözcüğe yükleyebileceği farklı anlam ilişkilerinin incelemesi yapılacaktır. Ayrıca eğer var ise söz konusu yapım eklerinin günlük kullanımda oluşturmuş, olduğu ifade kalıplarının da semantik boyutu ele alınacaktır.

\section{Amaç ve kapsam}

$\mathrm{Bu}$ çalışmanın amacı, yapım ekleri içerisinde sıklıkla kullanılan +lIk yapım ekinin bir sözcüğe semantik olarak kattığı farklı anlamları belirlemektir. Bugün birçok Avrupa dilinde söz konusu ekin karşılığı başka bir sözcük ile ifade edilirken (Tr. Kitaplık, İng. Bookshelf, Bookcase) dilimizde bu görevi sadece bir ek üstlenmektedir. Bu noktadan bakıldığında Türkçede kullanılan ekin sözcüğe kattığı anlam yoğunluğunun ne denli etkili olduğu görülmektedir. Sözcük türetme açısından zengin bir dil olan Türkçenin ekler aracılığı ile sözcüklere kazandırdığı yeni ve yoğun anlam çeşitliliği de bu yolla bir kez daha görülmektedir.

$\mathrm{Bu}$ çalışmada ele alınacak örnekler gündelik yaşantımızda sıkça kullandığımız sözcüklerden seçilecektir. Söz konusu ekin bilinen anlam ve görevi ile kullanıldığı birçok tanım ve örnek mevcuttur. Bu yüzden bu çalışmada ek kalıbının çarpıcı kullanımlarını ve farklı anlam yoğunluğuna sahip

\footnotetext{
Adres Address

İstanbul Medeniyet Üniversitesi, Eğitim Bilimleri Fakültesi, Türkçe ve Sosyal Bilimler Eğitimi Bölümü, Türkçe Eğitimi ABD Cevizli Turkish and Social Scinces Education, Turkish Language Teaching Kampüsü, Kartal-İstanbul/TÜRKIYE $\quad$ Education, Cevizli Campus, Kartal-İstanbul /TURKEY e-posta: editor@rumelide.com 1 e-mail: editor@rumelide.com
} 
kullanım tercihlerini ele alacağız. Özellikle de medyatik dil alanlarında yer alan örnekleri, sosyal medyadaki dil kullanımlarını ve günlük konuşma dilinde yer alan ve yazı diline yansımayan örnekleri tercih edeceğiz. Bu örnekler, özellikle de bazı özel mecralarda kullanılan ve jargon haline gelen kullanımlar, kullanıldıkları sosyal çevrenin özellikleriyle ve bu sosyal çevrenin dil ile kendini ifade etme biçimleriyle yorumlanacaktır. Bu yorumlama neticesinde ortaya çıkan veriler hem toplum-dil ilişkisi yönüyle hem de toplumdilbilimin ayrılık kuramıyla ele alınacaktır. Bu yolla, +llk yapmak veya +lIk etmek kalıbı ile kullanılan söz gruplarının ifade ettiği yeni anlamların semantik özelliklerinin vurgulanması hedeflenmektedir. Bu vesile ile çalışmanın bundan sonra ekler üzerine yapılacak çalışmaların semantik tasniflerinin oluşturulmasına katkı sağlayacağı düşünülmektedir.

\section{Bulgu}

Bildiğimiz tanımla yapım ekleri bir sözcüğe ulanarak onlardan yeni sözcükler türetmeye yarar. Çalışmamızda esas olarak kullanacağımız +lIk yapım eki ise eklendiği sözcüklere yer, meslek, alet, araç gereç, makam, rütbe, soyut, özellik, topluluk, bağlılık, sayı ve renk adları anlamı katarak yeni sözcükler türetir. Ayrıca söz konusu ek eklendiği kimi sözcüklerin türünü de değiştirerek sıfat göreviyle kullanılmasını sağlar. Ekin işlevleri ve farklı kullanımları ile ilgili çeşitli görüşler mevcuttur. Tahsin Banguoğlu (2007:193), Türkçenin Grameri adlı eserinde ekin çok işlek eklerimizden biri olduğunu ve çekim ekini andıran bir kullanışa sahip olduğunu dile getirmektedir. Ekin adlara gelerek "için takısı" anlatımında bir içinlik hali (destinatif) meydana getirdiğini aktararak şu örnekleri vermektedir: "elli kuruşluk bilet, üç günlük iş, yarınlık çay şekeri var.” Banguoğlu söz konusu ekin çok çeşitli anlatımlarda görülebileceğini dile getirerek yukarıda örneklendirilen adların türetilmesinde kullanıldığını dile getirmiştir.

Ergin (1998:155) ise, ekin başlangıçtan beri Türkçenin önemli isimden isim yapma eklerinden biri olarak kullanılan bir ek olduğunu ve hem geçici hem de kalıcı isimler yaptığını ifade etmiştir. Ayrıca bu eklerin kullanış bakımından tam bir genellik vasfına sahip olduğunu dile getirmiş ve yukarıda örneklendirilen isimlerin yapımında kullanıldığını ifade etmiştir.

Ayrıca, Gürer Gülsevin (2017:127), Eski Anadolu Türkçesinde Ekler kitabında ekin, isimler ve sıfatlardan soyut isimler yaptığını "açlık, beglik, kulluk, yoksulluk" örnekleriyle; isimlerden zaman bildiren sıfatlar yaptığını "kuşluk, yıllık" örnekleriyle; belirli bir devreyi gösteren isimler yaptığını "kocalık, lohusalık, yiğitlik" örnekleriyle; meslek ve meslek haline getirilmiş uğraşları gösteren isimler yaptığını "ogrulık, münkirlik, tabiblik" örnekleriyle; bir maddenin ne için uygun olduğunu gösteren sıfatlar yaptığını "kefenlik" örneğiyle; alet ismi türetmesini "tuzluk" örneğiyle; bitki adları yaptığını "sovukluk" örneğiyle ifade etmiştir.

Türkçe sondan eklemeli bir dil olduğu için eklerin sözcüklere ulamı şüphesiz yeni anlamların veya ifadelerin ortaya çıkmasını sağlamaktadır. Bu çerçeveden bakıldığında her bir ek yeni bir semantik yükü de beraberinde getirmektedir. Buna ek olarak söz konusu eklerin ulandıkları sözcüklerin türlerini de değiştirdikleri bilinmektedir. +lIk, eki genellikle adlardan ve sıfatlardan adlar türetmektedir. (Korkmaz, 2007:55) İncelediğimiz diğer kaynaklarda da +lIk yapım ekinin daha yeni adlar türetmede kullanıldığı görülmüştür.

Bunlara ek olarak, söz konusu eklerin bazı yardımcı fiil ve sözcüklerle kalıplaşarak farklı anlam ilgileri ifade ettiği örnekler de mevcuttur. +lIk yapmak, +lIk etmek şeklinde oluşmuş ve farklı anlam yükleri ile kullanılmış birçok örnek bulunmaktadır. Bu kalıplar ile ilgili kullanımları ilerleyen bölümlerde

\footnotetext{
Adres $\mid$ Address

İstanbul Medeniyet Üniversitesi, Eğitim Bilimleri Fakültesi, Türkçe İstanbul Medeniyet University, Faculty of Education Sciences, ve Sosyal Bilimler Eğitimi Bölümü, Türkçe Eğitimi ABD Cevizli Turkish and Social Scinces Education, Turkish Language Teaching Kampüsü, Kartal-İstanbul/TÜRKIYE $\quad$ Education, Cevizli Campus, Kartal-İstanbul /TURKEY e-posta: editor@rumelide.com 1 e-mail: editor@rumelide.com
} 
farklı örnekler üzerinde inceleyeceğiz. Ayrıca +lIk eki bazı yapım ekleri ile birleşerek yeni bir ek kalıbı da oluşturmuştur. Ortaya çıkan bu yeni ek kalıbı, bazı yardımcı fiillerle birleşerek farklı anlam ilgileri ile kullanılmıştır. Bu ekler ile oluşturulan anlam ilgilerini detaylı olarak incelemek ve günlük konuşma dilimizdeki ifade zenginliklerini belirtmek bu çalışmanın başlıca amacı olacaktır. Daha önce de belirttiğimiz gibi sözcüğün tek başına olan anlamı, bir ek alarak ifade ettiği anlamı ve bu şekli ile ifade edildiği bağlamdaki anlamı birbirinden farklıdır. Bu biçimde oluşan yeni anlamın sahip olduğu gösterge ise bağlamın çok üstünde bir anlam zenginliği ifade etmektedir.

Türkçedeki ek kalıplaşması olayları üzerine yapılan çalışmalarda da +lIk ekinin hâl ekleri ile kalıplaşıp yeni anlamlar ifade etmesi durumu ele alınmıştır. Zeynep Korkmaz, ek kalıplaşması olayını bir bütün olarak ele almış ve bazı çekim eklerinin görevleriyle kazandığı özellikler neticesinde ortaya çıan, türetme ve birleştirme özelliğini ek kalıplaşmaları ile beraber ele almış ve oluşan bu yeni yapıyı Türk dilinin sözcük varlı̆̆ını zenginleştiren yeni bir yol olarak değerlendirmiştir. Korkmaz’a (2008:13) göre ek kalıplaşması, sözcüğün cümle içindeki değişik kullanılışları ile ilgili bir anlam değişmesinin sonucudur. Bu değişim şekil bilgisi ile anlam bilgisini bir araya getiren bir dil olayıdır. Ayrıca bu durum türetme gibi dışarıdan müdahale ile olmaz, kendiliğinden oluşur.

Ergin (2009:156) ise, eklerin birleştikleri sözcüklere göre değişik görevler kazanmasını esas alarak bu ekin daha başka örneklerde daha başka görevleri bulunması olasılığının dikkate değer olduğunu vurgulamış ve bir ekin belli başlı görevleri ile beraber, birleştiği bazı kök ve gövdelerle ilgili özel anlam ve görevleri de olabileceğini ifade etmiştir. Hatta bazı durumlarda benzer bir görevle kullanılan örneklerde bile kök ve gövdelere bağlı olarak bir takım anlam farklılıkları ile karşımıza çıkabileceğini dile getirmiştir.

$\mathrm{Bu}$ söylenenlerden yola çıkarak bir sözcüğün manasının ek ve kök ilişkisinden ziyade kök veya gövdenin anlam yükü ile de zenginleşebileceğini ifade edebiliriz. Söz gelimi "gece" ve "gündüz" sözcüklerine ulanan +lIk eki sözcügün türüne aynı işlevde katkı sağlamaktadır. Fakat ek "gece" sözcüğüne ulandığında ortaya yeni ve anlaşılabilir bir anlam çıkarken aynı durum "gündüz" sözcüğü için söz konusu olmayacaktır. Yeni oluşan gövdenin ekin getirdiği semantik yükle beraber değerlendirilmesi gerekmektedir ve bu husus söz konusu kök veya gövdenin anlam derinliğidir. Çünkü "bir gövdenin manasında yapım ekinin rolü ne kadar büyük olursa olsun o gövdenin dayandı̆̆ kök veya gövde de hususi bir durum yaratabilir. Onun için bir ekin fonksiyonlarını kesin olarak kestirip atmamak ve bunların mevcut durumda bulunanlarını kaydettikten sonra başkalarının da bulunabileceği düşüncesi ile kapıyı açık bırakmak lazımdır.” (Ergin, 2009:156)

"Eşkıyalık, zulüm hakaret, hırsızlık, açlık, yağmacılık alevsiz bir yangın gibi bu bin senelik ana yurdunu yakıp tutuşturuyordu." (Ömer Seyfettin, 2009:118) Burada söz konusu edilen kullanımlar ekin fonksiyonu ile kalıcı isimler haline gelmişlerdir. Bu örneklerde kök ve gövdeye eklenen ekin ortaya çıkardığı yeni anlamların, kök ve gövde ile olan bağlantısı açık bir biçimde görülmektedir. Ekin kalıcı isimler yapması konusunda ise Jean Deny farklı bir yaklaşım sergilemiştir. Deny'e (2012:301) göre Türkiye Türkçesi ekin +lI biçimini sıfat türemine, +lIk biçimini ise ad türemine ayırmıştır. Deny (2012:302), Korkmaz'dan farklı olarak söz konusu ekin yalın ve somut anlamlı adlar meydana getirdiğini söylemiş ve bu tür kullanımları örnekleyerek yalın anlamlı olarak nitelendirdiği sözcükleri, bir sıfattan türemiş oldukları zaman, bir kişi adından türemiş oldukları zaman, cansız bir şey adından yapıldığı zaman, sadece “-e özgü” anlamıyla kullanıldı̆̆ı zaman, aynı sınıftan sözcüklerin belirsizlik anlamında kullanılacak yerde pek belirli bir anlam alarak kullanıldığı zaman, açık maddeleri bildirerek kullanıldı̆̆ zaman olarak beş gruba ayırmıştır.

\footnotetext{
Adres $\mid$ Address

İstanbul Medeniyet Üniversitesi, Eğitim Bilimleri Fakültesi, Türkçe İstanbul Medeniyet University, Faculty of Education Sciences, ve Sosyal Bilimler Eğitimi Bölümü, Türkce Eğitimi ABD Cevizli Turkish and Social Scinces Education, Turkish Language Teaching Kampüsü, Kartal-İstanbul/TÜRKIYE $\quad$ Education, Cevizli Campus, Kartal-İstanbul /TURKEY e-posta: editor@rumelide.com 1 e-mail: editor@rumelide.com
} 
Sıfattan türemiş olan sözcüklere verdiği örnekler; "güçlük, güzellik, çirkinlik, kötülük, fenalık, dalgınlık, çobanlık” gibi sözcüklerdir.

Kişi adından yapılmış olan yalın anlamlı sözcüklere; "babalık, analık, gelinlik, evlatlık, oğulluk" gibi örnekleri vermiştir.

Cansız bir şey adından yapılan sözcüklere ise; “yemlik, karşlık, odalık, cennetlik, elbiselik” örneklerini vermiştir. (Deny, 2012:303)

-e özgü anlamıyla kullanılan ve sıfat olarak görev yapan sözcüklere; "yazlık tiyatro, kışlık elbise gömleklik bez, gecelik klyafet” örneklerini vermiştir.

Aynı sınıftan kelimelerin belirsizlik anlamında kullanılacak yerde pek belirli bir anlam alarak kullanıldığı sözcüklere; "yemlik, tozluk, yağlık, ağızlık, kolluk, fişeklik” örneklerini vermiştir. (Deny, 2012:304)

Deny, +lIk eki ile kullanılan sözcüklerin tek başlarına sadece belirli bir anlamı ifade edecek biçimde kullanılmasını yalın anlamlı olarak değerlendirmiştir. Her ne kadar bu şekilde bir değerlendirme yapsa da sözcüklerin anlam ifadelerinin kullanıldıkları bağlam ile birlikte değerlendirilmesi gerekmektedir. Dolayısıyla sözcüklere eklenen bu ek, sözcügün yalın anlam olarak kalıcı bir anlam ifadesi ile kullanılması noktasında zaman zaman yetersiz ve geçersiz bir işlevde bulunabilir. Buradaki türetme durumuna bu şekilde bakarsak, ekin yalın anlamlı sözcükler türetebileceği fikri kabul edilse de bu sözcüklerin anlamlarının yalınlığı sabit ve genel geçer değildir. Deny, söz konusu ekin eklendiği sözcüklere kattığı anlam özelliğinin sınıflandırılması bakımından önemli bir görüş ortaya koymuştur. Aynı yaklaşım Korkmaz tarafından ek ile türetilen sözcüklerin "tashih anlamı katacak şekilde bir kullanımı olduğunun” (Korkmaz, 2007:55) belirtilmesi ile de ifade edilmiştir.

Muharrem Ergin, bu durumu bir yöntem olarak kabul edip, başka ekleri de bu şekilde değerlendirebileceğini ifade etmiştir. Ayrıca Ergin +lIk ekinin bazı örneklerde çekim ekinden sonra gelerek özel bir kullanıma da sahip olduğunu belirtmiş ve gün-de-lik, on-da-lık örneklerini vermiştir. Burada gördüğümüz ek kalıplaşmasında +DA eki asli görevi ile kullanılmamış ve +lIk ekinin semantik yükü ile başka bir durumu ifade eden bir biçimde kullanılmıştır. Bir yapım ekinin bir çekim ekinden sonra gelmesi olası bir durum değildir. Ergin bu durumu çekim ekleri arasında olan -da, -de 'nin çekim eki görevinin kaybolduğunu ve +lIk eki ile birleşerek -DAlIk şeklinde tek bir ek gibi ayrılmaz bir bütün meydana getirdiğini ifade ederek izah etmiştir.

Aynı durum farklı bir çalışmada da ele alınmış ve hal eki kalıplaşmalarında en çok dikkati çeken hususlardan birinin +Ilk ekinin hal ekinden sonra gelmesi durumu olduğu vurgulanmıştır. (Özkan, 2001:157) Makalesinde bu durumu ele alan Nevzat Özkan (2001:157), bu kalıplaşmaya Türkiye Türkçesindeki sıkça kullanılan bir sözcük olan "üstelik" sözcüğünü örnek göstermektedir. "Bu sözcüğün Türkçe sözlükte iki ayrı kullanılışı verilmektedir: is. 1. üste verilen şey: "Saatimi bu kalemle değiştirdim, bin lira da üstelik aldım" 2. zf. Ayrıca, bir de bundan başka: "Üstelik bu sene dimağımda büyük bir yorgunluk duyuyorum" (A.Ş. Hisar). Bu sözcük üste vermek "bir şeyi başka bir şeyle değiştirirken fazladan vermek" ve üste vurmak "fiyatını artırmak, eklemek, katmak" birleşik fiillerinde isim unsuru olarak bulunmaktadır. Ayrıca bu sözcüğün üste "fazladan vermek, caba" şeklinde isim olarak kullanılışı da bulunmaktadır. Bu örneklerden hareketle +lIk ekinin, hal ekiyle fiile bağlanmış bir isme, fiilin değişik sebeplerle zaman içinde düşürülmesi sonucu, mastar anlamı katmak üzere

\footnotetext{
Adres $\mid$ Address

İstanbul Medeniyet Üniversitesi, Eğitim Bilimleri Fakültesi, Türkçe İstanbul Medeniyet University, Faculty of Education Sciences, ve Sosyal Bilimler Eğitimi Bölümü, Türkçe Eğitimi ABD Cevizli Turkish and Social Scinces Education, Turkish Language Teaching Kampüsü, Kartal-İstanbul/TÜRKIYE $\quad$ Education, Cevizli Campus, Kartal-İstanbul /TURKEY e-posta: editor@rumelide.com 1 e-mail: editor@rumelide.com
} 
geldiğini düşünebiliriz. Zira +Ilk eki, gelmek/lik, almak/lık örneklerinde görüldüğü gibi mastar eki üzerine bu ekin fonksiyonunu kuvvetlendirmek üzere gelebilmektedir.”

Hem Ergin hem de Özkan'ın açıklamalarından yola çıkarak +lIk ekinin hal eki üzerine gelerek oluşturduğu yapıda +lIk ekinin anlam yoğunluğunun daha ön plana çıarak oluşan kalıbın yeni bir anlam ifadesi ile kullanıldığını ve bu kalıbın eklendiği sözcüklerde oluşan yeni anlamın +lIk ekinin bildiğimiz görevlerinden başka yeni bir anlam yükü ile sözcüklere ulandığını söyleyebiliriz.

\section{4. +lIk Yapmak/ +lIk Etmek söz grubunun ifade ettiği anlamlar}

+lIk yapmak / +lIk etmek söz grubunu bir ifade kalıbı olarak ele aldığımızda ve bu kullanımı esas alarak bağlam merkezli bir değerlendirme yaptığımızda farklı anlamlar ile kullanıldığını söyleyebiliriz. Ek, bu durumda yukarıdaki söz konusu ettiğimiz türlerin dışında sentaktik olarak farklı bir görevde bulunur. +lIk yapmak / +lIk etmek kalıbı daima yükleme en yakın öğede bulunan sözcükte bulunur ve vurgu bu sözcük üzerindedir. İşte bu konum ve vurgu bu söz grubunun ilgili sözcüğe ulamı ile ortaya çıkmaktadır. Uyuzluk yapmak, kılıbıklık yapmak, yaramazlık yapmak, gevezelik etmek gibi örnekler bu tür kullanımlara örnektir. Burada öne çıkan anlam "olma durumu" anlamıdır. Yani uyuzluk yapmak bir kimseye ait ve süreklilik arz eden bir durum değildir fakat o anki bağlamda sergilenen anlık bir davranışı ifade etmektedir. Bu ifade biçimi derin yapıda "uyuzluk yapmak" gibi bir davranış biçimi yaratmaktadır. Bu ifade kalıbının içinin doldurulması ise bireysel veyahut fevri bir davranışın yarattığı izlenimdir. Benzer bir durum sosyal ortamda ve medyatik dil alanlarında çokça kullanılan bir kalıp olan "cinslik yapmak" örneğinde de görülmektedir. Cins sözcüğünün bu bağlamdaki ifade ettiği anlam evreni; kendine has özellikleri olan, başka, ayrı, ayrılıkçı, uyumsuz gibi kullanımlardır. Diğer bir bakış açısı ile "cins" sözcüğüne ulanan “+lIk" yapım eki bazı durumlarda yüksek nitelikli olma anlamı da ifade etmektedir. "Atın cinsliği ilk bakışta belli oluyordu." Bu noktadan bakıldığında yeni oluşan sözcüğün anlamı ile akla gelen ilk anlamı arasında zıt bir anlam ilişkisi bulunmaktadır.

Bağlam ve icra noktasında değerlendirme yapıldığında farklı anlam ihtivası ile kullanılan bir başka örnek ise gevezelik etmek söz grubudur. Gevezelik etmek Türkçe Sözlükte; 1. Saçma sapan konuşmak, zevzeklik etmek, 2. Yarenlik etmek anlamları ile verilmiştir (TDK Sözlük, 2005:755) "Bugün iki iyi dost gibi gevezelik ettiler.” (Uşaklıgil, 2008:426) cümlesinde de görüleceği gibi literatürdeki yer alan örneklerin genellikle sözlük anlamı ile kullanıldığı dikkat çekmektedir. Söz grubu günlük konuşma dilinde ise sözlük anlamının dışında bir davranış biçimini ifade edecek biçimde kullanılmaktadır. Yerinde duramayan, sürekli hareket eden ve gürültü çlkaran kimseler için de gevezelik etmek söz grubu kullanılmaktadır. Bu bağlamda söz grubu yaramaz anlamı ihtivası ile kullanılır ve sadece sözlü bir davranış değil aynı zamanda fiziksel birtakım davranışları da içermektedir.

Bu örneklerden hareketle +lIk yapmak, +lIk etmek kalıbının eklendikleri sözcüklere genel geçer bir anlam ifadesi katmadığını bunun aksine kişiden kişiye veya durumdan duruma değişen tavır veya davranışların ifadesinde kullanıldığını söyleyebiliriz. Ama +lIk ekini bir sözcüğün üzerine tek başına eklediğimizde kalıcı isimler veya sıfatlar yaptığını yukarıdaki bölümlerde izah etmiştik.

Terbiyesizlik etmek/yapmak, kullanımında da benzer bir durum görülmektedir. Bu kalıbın sözlük anlamı "toplum kurallarına, görgü kurallarına aykırı davranışta bulunmak" olarak geçmektedir. (TDK Sözlük, 2005:1958) Ama söz grubu sadece toplum ve görgü kurallarına aykırı davranışı ifade etmek için kullanılmamıştır. Söz gelimi; "Biz de sevdik, biz de terk edildik, kimi zaman bizi sevdiklerimizden

Adres

İstanbul Medeniyet Üniversitesi, Eğitim Bilimleri Fakültesi, Türkçe ve Sosyal Bilimler Eğitimi Bölümü, Türkçe Eğitimi ABD Cevizli Kampüsü, Kartal-İstanbul/TÜRKIYE e-posta: editor@rumelide.com 
ayırdığını sandıklarımıza biz de kin kustuk içten içe... ama hiçbir zaman terbiyesizlik yapmadık" (https://eksisozluk.com/terbiyesizlik--172581?p=1)

Yukarıdaki örnekte de görüleceği gibi +sIzlIk yapmak söz grubu zaman zaman sözlük anlamının dışında bir anlam ile kullanılmıştır. Burada vurgulanmak istenen şey, bir insanın toplum ve görgü kurallarına uyması ya da uymaması değil sergilenen davranışın toplum ve görgü kurallarına uygun olsun veya olmasın kendisine veya bir başkasına yakışmaması durumunu içermesidir.

Bu tür kullanımlara başka bir örnek ise dengesizlik yapmak, dengesizlik etmek söz grubudur. Bu söz grubunun içerdiği anlam Türkçe Sözlükte bulunmamaktadır. +sIzlIk yapısının görüldüğü bu söz grubunda da ilk bakışta dengeden yoksun olma durumu ve bu durumun neticesinde sergilenen davranışları karşılayacak bir anlam ihtivası söz konusudur. Ama bu söz grubunun ifade ettiği anlam, denge sözcügünün mecazi anlamından hareketle bir insanın huy, ahlak ve davranışta kararlı olmaması anlamını içermektedir. Buradan hareketle bu söz grubunun kullanıldığı bağlamlarda, bu durumla yargılanan biri huy, ahlak ve davranışta kararsızdır. Dolayısıyla dengeden yoksun olma durumunu ifade eden bu söz grubu şartlara, çevreye ve duruma göre değişebileceğinden durağan bir anlam içermez. Söz gelimi, bir ortamda alakasız bir söz etmek dengesizlik yapmak ile nitelendirilirken diğer bir taraftan bir oyun esnasında sergilenen yanlış ya da ters bir davranış da dengesizlik yapmak veya etmek olarak nitelendirilebilir. Özellikle, sosyal medyada ve günlük konuşma dilinde sıkça kullanılan bu söz grubunun anlam evreni daha çok mizahi bir unsur, hiddet ve kızma anlamı ihtivası ile kullanılmıştır.

Yukarıda verilen örneklerden hareketle, +lIk+yardımcı fiil ve +sIzlIk+ yardımcı fiil yapısının doğrudan bir şeyin olma veya yok olma ifadesinin yanı sıra, birer davranış biçiminin ifade edilmesi yönüyle de kullanıldığını söyleyebiliriz. Verdiğimiz örneklerden hareketle yapılan bir davranış veya hareketin ekin ulandığı sözcüğün türü ve anlamına göre gerçekleştirilmesi veya gerçekleştirilmemesi durumu söz konusudur. Yani, terbiyesiz bir kimse terbiyesizlik yapar, kurnaz biri kurnazlık yapar. Burada itham edilen kişinin bir davranışı veya kendine has bir özelliği bu biçimde ifade edilir ve bu özelliği vurgulanir.

Benzer bir durumda +lIk yapmak veya +lIk etmek kalıbının benzetme veya yakıştırma anlamı ifade edecek biçimde kullanılmasında görülmektedir. Söz gelimi çakal sözcüğüne ulanan +lIk eki ile türetilen çakallık sözcüğünde, çakala özgü bir davranışın belirli bir durum veya olay karşısında insana atfedilmesi durumu söz konusudur ve çakallık yapmak bu durumun ifadesi için kullanılan bir söz grubudur. Çakal sözcüğü argo olarak, kurnaz, yalancı, düzenci, aşağılık kimse anlamında kullanılmaktadır. (TDK Sözlük, 2005:382) Çakallık yapmak ise burada verilen tavır ve davranışları sergileyen bir insanı ifade etmek için kullanılabilir. Burada verilen özellikler çakalın bünyesinde veya bir hayvan olarak karakterinde bulunmamasına rağmen yakıştırma anlamı ifade edecek biçimde insana atfedilir. Hayvanlara ait bazı özelliklerin insanlara atfedilmesi ile ortaya çıkan benzetme ilgilerinin çokça kullanıldığını hem yazı dilinde hem de konuşma dilinde sıkça görmekteyiz. Fakat zaman zaman bu durumun dışında kalan ve konuşma dilinde yer alan fakat yazı diline yansımayan kullanımlarda vardır. Söz gelimi öküzlük sözcüğü; budalalık, sersemlik, budalaca ve sersemce iş anlamları ile sözlükte yer almaktadır. (TDK Sözlük, 2005:1536) Söz konusu sözcüğün öküzlük yapmak ya da öküzlük etmek şeklindeki kullanımlarını günlük konuşma dilinde argo ifadesi olarak yoğun bir şekilde görmekteyiz. Öküzlük etmek, çok kaba davranmak anlamı ile kullanılmaktadır. (www.lugatim.com/s/öküzlük) Diğer bir taraftan beklenmeyen bir durumu sergileyen bir kimse içinde bu ifadenin kullandığı durumlarda mevcuttur. "Bence erkeğin öküzü diye bir şey yok; duyguları şu ya

Adres
Address

Istanbul Medeniyet University, Faculty of Education Sciences,

Turkish and Social Scinces Education, Turkish Language Teaching

Education, Cevizli Campus, Kartal-İstanbul /TURKEY

e-mail: editor@rumelide.com 
da bu şekilde hadım edilmiş insanları öküze dönüşmesi ya da öküzlük yapması var sadece. Örneği ve Başkalarına öküz derken öte yandan kendi yoksunluklarımız nedeniyle öküzlükler yapışlarımız..." (https://www.medyafaresi.com/haber/14-maddede-bir-erkegin-okuz-olup-olmadigi-nasil-

anlasilir/800159). Verilen örneklerde de görüldüğü gibi sadece kaba olması yönüyle bir davranışın öküzden insana geçmesinin yanı sıra duyguları hadım edilen dolayısıyla bu nedenle de kabalaşan kimseler içinde öküzlük yapmak deyişinin kullanıldığını görmekteyiz. Bunlardan farklı bir durum olarak bazı sosyal ve medyatik platformlarda bulunan videolarda kapıyı kırıp içeri giren, tavana ayakkabı fırlatan, arkadaşının arkasından tekme atan kimseler için de "öküzlük yapma" ifadesi kullanılmaktadır. Burada sergilenen hiçbir davranış bir öküz tarafından gerçekleştirilmez, yani bir öküz arkadaşına arkadan tekme atmaz, kapıyı omuzlayıp içeri girmez ve tavana ayakkabı atmaz kaldı ki ayakkabı da giymez. Bu tür kullanımları çeşitlendirmek mümkündür, aynı durum mallı yapmak kullanımı için de geçerlidir. Daha çok argoda karşılaştığımız bu söz grubunun anlam ifadesi de öküzlük yapmak söz grubundaki anlam içeriğine paraleldir. Bu söz grubu sosyal ağda "Mal olma durumudur. Mallık, bir olay karşısında, kişinin olağanın dışında malca bir tepki vereceğinin farkında olmasına rağmen, o tepkiyi vermekten kaçınmamasıdır. Dolayısıyla, mallık bir tutumdur; bir duruştur." (https://www.uludagsozluk.com/k/mall\%C4\%B1k/\#) Buradan hareketle mallık yapmak ifadesinin bir kişinin sadece bilinçsizce bir tavır veya hareketle sergilediği bir durum ya da davranışın neticesinde sarf edilen bir söz grubu olarak nitelendirilebileceği kanaatine varabiliriz. Bu kullanım da yine bir önceki söz gruplarında olduğu gibi yakıştırma anlamı ifadesi ile izah edilebilir. Zira o anki koşul ve şartları ele aldığımızda sergilenen davranışın bir mal (genel olarak hayvan) tarafından yapılabileceği bir durum söz konusudur. Burada yakıştırma ilgisi oradaki davranışın gerçekten bir mal tarafından sergilenip sergilenmemesi değil, o davranışın bir mala yakıştırılmasıdır. Bu örnekte de görüleceği gibi bu söz grubunda yakıştırma vurgusunun yapıldığı görülmektedir.

Bu yapı ile kullanılan bir başka söz grubu ise hryarlık etmek söz grubudur. Burada diğer söz gruplarından farklı olarak bir bitki ile yakıştırma vurgusu bulunmaktadır. Hıyarlık etmek söz grubu Türkçe Sözlükte, hıyarlaşmak anlamı ile verilmiştir. Hıyarlaşmak sözcügü ise sözlükte ayrı bir madde başı olarak; kaba saba, budalaca davranışlarda bulunmaya başlamak anlamı ile yer almaktadır. (TDK Sözlük, 2005:887) Buradaki anlamsal bağlamda, diğer örneklerde de görüldüğü gibi, istenmeyen veya uygun olmayan bir davranış biçiminin ihtivası söz konusudur. Bu söz grubunun kullanıldığı bağlamlarda bir kişinin davranışının hıyar olarak betimlenmesi aslında bir bitki olarak hıyarda bulunmayan bir vasıf ile ifade edilmiştir. Burada hıyarın davranış sergilemesinden ziyade sergilenen bir davranışa uygun bir karakter olarak görülmesi söz konusudur. Hıyar, böylesi bir durumda sergilenen davranışın ifadesi olarak kendi tabiatının dışında farklı bir yakıştırma ilgisi ile kullanılmıştır. Kısacası hareketi bir hıyar asla yapmamıştır hatta yapamayacaktır ama bu hareketi biri yapsaydı eğer en iyi bir hıyar yapardı ve o davranışı da bir kişi gerçekleştirdi. Gerçekleştiren bu kişi de olsa olsa hıyar olurdu, ifadesi bulunmaktadır.

Verdiğimiz örneklerden hareketle; +lIk yapmak veya +lIk etmek yapısının eklendiği sözcüklere istenmeyen bir davranış veya hareket anlamı kattığını ve bu durumun eyleme dönüşme ifadesi ile kullanıldığını söyleyebiliriz. Ek bu fonksiyon ile müstakil biçiminden daha fazla bir anlam yoğunluğuna sahiptir. Bu yapının eklendiği sözcükler kendisine benzetilen vasfı ile ön planda bulunmaz. Aksine kendisine yakıştırılan ama kendisinde doğal olarak bulunmayan bir özelliğin ifadesinde kullanılmaktadır. Söz grubu bu durumda "gibi davranmak" anlamı ile kullanılır. Fakat verilmiş olan örneklerde de görüleceği gibi buradaki davranış benzetme ilgisi güdülen varlık veya canlıda çoğu zaman bulunmaz. 
+lIk yapmak veya +lIk etmek kalıbı ile kullanılan başka bir söz grubu da özel isimlerdir. Bu söz grubu, toplumun beğenisini kazanmış, ilgi ve takdir gören, belirli bir özelliği ile ön planda olan veya olumsuz bir yönü ile öne çıkan bir karakter adına ulanarak kullanılabilmektedir. Söz grubu, o karaktere özgü davranış sergileyen kimseleri ifade etmek için kullanılmaktadır. Söz gelimi bir Amerikan çizgi dizisi olan Simpsonlar karakteri Homer'in bazı tutum ve davranışlarının Homerlik yapmak olarak nitelendirildiği görülmektedir. Çizgi dizide, Homer çalıştığı nükleer santrali bir tekerleme aracılığıyla seçtiği düğmeye basarak patlamaktan şans eseri kurtarır. Bu tesadüfi durum Homer’i kahraman yapar. Homerlik yapmak kalıbının farklı platformlarda ve günlük konuşma dilinde ihtiva ettiği anlam, Homer’in dizi boyunca sergilediği davranışları ifade edecek biçimde kullanılmaktadır. Homer’in kontrolsüzce ve ahmakça yaptığı hataların sonunda kahraman olması, Homerlik yapmak deyiminin "bilmeyerek işe yarar bir şey yapmak" olarak anlam kazanmasına ve benzetme ilgisi ile bu durumu sergileyen kimseler için kullanılmasına olanak sağlamıştır.

Bu tür kullanımların genellikle sosyal medyada ve argo dilinde kullanılması dil kullanımının farklı toplum tabakaları arasında icra biçimi ile alakalıdır. Bugün gerek yazı dilinde gerekse de konuşma dilinde çok sık sarf edilmeyen, sözlük maddelerinde bulunmayan bu tip kullanımlara toplumun belirli bir tabakasında rast gelinmesi tesadüfi bir durum değil, aksine kullanılan dilin o tabaka veya grup arasındaki iletişimin boyutu ile alakalıdır.

Bir toplumdilbilimci olan William Labov, toplumsal tabakalar arasındaki bu tür farklı kullanımları ayrılık kuramı ile açıklamaktadır. Labov toplumsal tabakalar arasındaki bu ayrılığı, "toplumdilbilim alanında kendi yaptığı araştırmaların sonuçlarına dayanarak açıklamıştır. Bu çalışmalar 'anlatım yetisi, sözcük zenginliği, dilbilgisellik, ölçünlü olmayan İngilizceyi konuşanların mantığı noktalarından yola çıkılarake gerçekleştirilmiştir. (İmer, 1987:217)" Labov, toplumdilbilimsel kuramında, "bir dil toplumunun sosyoekonomik tabaka sürecinin, konuşmacıların dilsel davranışlarında ayrılıklar oluşturduğu hipotezinden yola çıkmaktadır. (König, 2010: 2)” Bu kurama göre, farklı sosyal grupların dil kullanım şekilleri, ifade imkânlarının farklılı̆̆ı ve genişliği açısından aynı işlevselliğe sahiptir. Aynı zamanda mantıksal bağlamın algılanması da her iki grup kullanımında aynıdır (Linke vd. 2001: 302). Bu bilgilerden yola çıkarak, +llk yapmak veya +lIk etmek kalıbının argo veya sosyal a ğ ortamında konuşulduğu bağlamda mevcut olan sosyal tabaka ortaklı̆̆ı, söz konusu ifadenin anlamsal özelliklerini bireyden canlı veya cansız başka bir şeye yüklemektedir. Bu durumda toplum içerisinde bir hayvan veya nesnenin insanın hareket ve davranışlarında ortaya çlkmasının ya da bir dışa vurum olarak sergilenmesinin yükleme yönü değişmiştir. Bu sosyal tabakaya göre burada kullanılan ifade biçimi doğrudur ve kullanılmasında da herhangi bir sakınca bulunmamaktadır. Burada sakıncadan kast ettiğimiz şey, bu ifade kalıbının ölçünlü dilde veya üst tabaka olarak belirtilen topluluklarda kullanılmaktan kaçınılmasıdır. Çünkü, argo veya absürt olarak dilde bulunan bu tür kullanımların anlam içeriği o toplulukta hem şeklen hem de içerik olarak bulunmamaktadır.

\section{Sonuç}

Sonuç olarak, günlük konuşma dilinde +llk yapmak / +lIk etmek kalıbının ulandığı sözcüklerde istenmeyen bir davranış biçimin dışa vurumu ifade edilmektedir. Bu davranış biçimleri kimi zaman anlık gelişen bir durum karşısında o anki davranışı ifade etmek için kullanılırken kimi zaman da kişisel bir davranış veya düşüncenin beklenilenin dışında farklı bir tavırla dışa vurumu ile ifade edilmektedir. Dolayısıyla söz grubunun ifade ettiği anlam içeriği şartlara, çevreye ve kişilere göre değişebilmektedir.

Adres

İstanbul Medeniyet Üniversitesi, Eğitim Bilimleri Fakültesi, Türkçe ve Sosyal Bilimler Eğitimi Bölümü, Türkce Eğitimi ABD Cevizli Kampüsü, Kartal-İstanbul/TÜRKIYE e-posta: editor@rumelide.com 
Yukarıda söz konusu ettiğimiz terbiyesizlik yapmak, uyuzluk yapmak, cinslik yapmak, öküzlük yapmak, mallı yapmak, hıyarlık etmek gibi örneklerin beklenilenin dışında bir durum veya davranış gösteren kimseler için kullanıldığını, buradaki kullanımın benzetme ilgisinin bilinenin tersi yöne işlediğini ve hayvana veya cansız bir varlığa benzetme ilgisinden ziyade insandan bu varlıklara yakıştırma ilgisinin güdülerek kullanıldığını ve cümledeki vurgunun bu ifade üzerinde yer aldığını söyleyebiliriz. Bir başka deyişle +lIk yapmak / +lIk etmek kalıbı, insandaki bir davranış biçiminin insan dışındaki canlı veya cansız bir varlığa yakıştırılması anlamı içerecek biçimde de kullanılmaktadır.

Ayrıca, +lIk yapmak/+lIk etmek kalıbı; sosyal ağda, orta tabaka olarak adlandırabileceğimiz ve argonun yoğun olarak kullanıldığı sosyal tabakada, Z kuşağı olarak adlandırılan genç kuşak arasında sıkça kullanılan bir yapı olarak karşımıza çıkmaktadır. Bu durum bu tür ifade biçiminin bir toplum tabakasına ait bir jargon olabileceğini işaret edebilir. Bununla beraber, bu kalıbının kullanıldığı bazı söz gruplarının sözlüklerde madde başı olarak bulunduğu (terbiyesizlik etmek, hiyarlk etmek) görülmüştür. Fakat, öküzlük, çakallık, eşeklik gibi sözcüklerin konuşma dilinde +lIk etmek / +lIk yapmak kalıbı ile kullanıldığı görülmüştür. Bu şekilde kullanılan söz gruplarının da sözlüklerde madde başı olarak alınması ya da ilgili madde başının altında bu anlam ilgisi ile verilmesinin dil kullanımının çeşitliliğ̈inin vurgulanması açısından önemlidir.

\section{Kaynakça}

Aksan, D. (2009). Anlambilim-Anlambilim Konuları ve Türkçenin Anlambilimi. Ankara: Engin.

Banguoğlu, T. (2007). Türkçenin Grameri. Ankara: TDK.

Deny, J. (2012). Türk Dil Bilgisi. (Çev. Ali Ulvi Elöve). İstanbul: Kabalcı Yayınevi (Orijinal Yayın Tarihi, 1921).

Derrida, J. (2020). Yazı ve Fark. (Çev. P. Burcu Yahım). İstanbul: Metis.

Ekşi Sözlük, Terbiyesizlik Başlı̆̆ı (2020, 18 Ekim) Erişim Adresi: https://eksisozluk.com

Ergin, M. (2005). Türk Dil Bilgisi, İstanbul: Bayrak.

Guiraud, P. (1999). Anlambilim. İstanbul: Multilıngual.

Günay, V. D. (1991). Dil Konuşanın Özelliğini Ne Oranda Yansıtır? Dilbilim Araştırmaları. s. 71-74.

İmer, K. (1987). Toplum Dil Bilimin Kimi Kavramlarına Kuramsal Bir Bakış ve Dil Türleri. Ankara Üniversitesi Dil ve Tarih-Coğrafya Fakültesi Dergisi C. 31 S. 1.2 Sayfa: 213-230

Karaağaç, G. (2013). Anlam (Anlam Bilimi ve İletişim). İstanbul: Kesit.

Karahan, L. (2006). Türkçede Söz Dizimi. Ankara: Akçă̆.

Korkmaz, Z. (2007). Türkiye Türkçesi Grameri Şekil Bilgisi. Ankara: TDK.

Korkmaz, Z. (2018). Türkçede Eklerin Kullanılş̧ Şekilleri ve Ek Kalıplaşması Olayları, Ankara: TDK.

König, C. (2010). Die Differenzkonzeption von William Labov: Eine kritische Reaktion auf die DefizitHypothese Basil Bernsteins, GRIN Verlag, Norderstedt

Kubbealtı Lügati, Öküzlük Maddesi, (2020, 20 Ekim) Erişim Adresi: http://www.lugatim.com

Medya Faresi, Öküzlük, https://www.medyafaresi.com/haber/14-maddede-bir-erkegin-okuz-olupolmadigi-nasil-anlasilir/800159

Özkan, N. (2001). Hal Ekleri Kalıplaşmaları ve Sebepleri Üzerinde Bir Değerlendirme. İlmi Araştirmalar 12, s. 153-165.

Palmer, F.R. (2020). Semantik, Yeni Bir Anlambilim Projesi. (Çev. Ramazan Ertürk). Ankara: Ayrıntı.

\footnotetext{
Adres $\mid$ Address

İstanbul Medeniyet Üniversitesi, Eğitim Bilimleri Fakültesi, Türkçe $\quad$ İstanbul Medeniyet University, Faculty of Education Sciences, ve Sosyal Bilimler Eğitimi Bölümü, Türkce Eğitimi ABD Cevizli Turkish and Social Scinces Education, Turkish Language Teaching Kampüsü, Kartal-İstanbul/TÜRKIYE $\quad$ Education, Cevizli Campus, Kartal-İstanbul /TURKEY e-posta: editor@rumelide.com 1 e-mail: editor@rumelide.com
} 
Sarı, M. (2014). Türkçenin Batı Dilleriyle İlişkisi. Ankara: TDK.

Toparlı, R. (Ed.) (2005). Türkçe Sözlük. Ankara: TDK.

Güncel Türkçe Sözlük Çalışma Grubu, (2005). Türkçe Sözlük. Ankara: TDK.

Uludağ Sözlük, Mallık Başlı̆̆ı, (2020, 22 Ekim) Erişim Adresi: https://www.uludagsozluk.com Uşaklıgil, H. Z. (2008). Aşk-ı Мemnu. İstanbul: Özgür.

Vardar, B. (2002). Açıklamalı Dilbilim Terimleri Sözlüğü. İstanbul: Multilingual. 